\title{
KAPASITAS ANTIOKSIDAN PADA BLACK GARLIC TUNGGAL DAN MAJEMUK SECARA IN-VITRO DENGAN DPPH
}

\author{
(ANTIOXIDANT CAPACITY OF SINGLE AND MULTIPLE BLACK GARLIC \\ IN-VITRO WITH DPPH)
}

\author{
DEWA AYU IKA PRAMITHA ${ }^{1}$, NI KOMANG GITA SUNDARI ${ }^{1}$ \\ ${ }^{1}$ Program Studi D3 Farmasi Fakultas Farmasi Universitas Mahasaraswati Denpasar
}

\begin{abstract}
Abstrak: Bawang putih (Allium sativum L) merupakan salah satu jenis tanaman yang telah banyak dimanfaatkan baik di bidang pangan maupun kesehatan. Kandungan senyawa yang terdapat dalam umbi bawang putih diantaranya adalah allicin dan sulfur amino acid alliin. Beberapa penelitian telah menunjukan berbagai pengaruh farmakologis dari bawang putih, misalnya sebagai antibakteri, antijamur, antihipertensi, antikanker, dan menunjukan efek perlindungan yang berkaitan dengan sifat antioksidannya. Bawang putih dapat diolah dengan cara fermentasi dan menghasilkan bawang hitam (black garlic). Black garlic merupakan produk fermentasi dari bawang putih yang dipanaskan pada suhu $65-80^{\circ} \mathrm{C}$ dengan kelembapan $70-80 \%$ dari suhu kamar selama satu bulan. Black garlic memiliki warna hitam dan ringan karena kadar airnya berkurang serta memiliki aroma dan rasa yang tidak terlalu menyengat seperti bawang putih. Terdapat dua jenis bawang putih yang dapat dijadikan black garlic, yaitu bawang putih tunggal dan majemuk. Tujuan penelitian ini adalah untuk mengetahui aktivitas antioksidan black garlic tunggal dan majemuk secara in-vitro dengan DPPH. Proses fermentasi dilakukan selama 3 minggu didalam magic com. Pengujian aktivitas antioksidan black garlic dilakukan dengan menggunakan DPPH sebagai sumber radikal dan diujikan dengan spektrofotometer UV-Vis. Hasil penelitian menunjukkan bahwa black garlic tunggal dan majemuk memiliki kapasitas antioksidan sangat kuat dengan nilai secara berturut-turut sebesar 1,529 ppm dan 1,602 ppm ekivalen asam galat.
\end{abstract}

Kata Kunci: antioksidan, black garlic majemuk, black garlic tunggal, DPPH

\begin{abstract}
Garlic (Allium sativum L) is a type of plant that has been widely used in both the food and health sectors. The content of compounds found in garlic bulbs includes allicyn and sulfur amino acid alliin. Several studies have shown various pharmacological effects of garlic, for example as antibacterial, antifungal, antihypertensive, anticancer, and show protective effects related to its antioxidant properties. Garlic can be processed by fermentation and produces black garlic. Black garlic is a fermented product of garlic that is heated at a temperature of $65-80^{\circ} \mathrm{C}$ with a humidity of $70-80 \%$ from room temperature for one month. Black garlic has a black and light color because the water content is reduced and has an aroma and taste that is not too strong like garlic. There are two types of garlic that can be used as black garlic, namely single and compound garlic. The purpose of this study was to determine the antioxidant activity of single and compound black garlic in vitro with DPPH. The fermentation process is carried out for 3 weeks in magic com. Black garlic antioxidant activity testing was carried out using DPPH as a radical source and tested with a UV-Vis spectrophotometer. The results showed that single and compound black garlic has a very strong antioxidant capacity with values of $1.529 \mathrm{ppm}$ and $1.602 \mathrm{ppm}$ equivalent to gallic acid, respectively.
\end{abstract}

Keywords: antioxidants, DPPH, multiple black garlic, single black garlic.

\section{PENDAHULUAN}

Bawang putih (Allium sativum L) merupakan salah satu jenis tanaman yang telah banyak dimanfaatkan baik dibidang pangan maupun kesehatan. Kandungan senyawa yang terdapat dalam umbi bawang putih diantaranya adalah allicin dan sulfur amino acid alliin. Beberapa penelitian telah menunjukan berbagai pengaruh farmakologis dari bawang putih, misalnya sebagai antibakteri, antijamur, antihipertensi, antikanker, dan menunjukan efek perlindungan yang berkaitan dengan sifat antioksidannya (Ambarsari, 2013; Anytah, 2013).

Bawang putih dapat diolah dengan cara fermentasi dan menghasilkan bawang hitam (black garlic). Black garlic merupakan produk fermentasi dari bawang putih yang dipanaskan pada suhu 65$80^{\circ} \mathrm{c}$ dengan kelembapan $70-80 \%$ dari suhu kamar selama satu bulan (Wange et al, 2010). Black garlic memiliki warna hitam dan ringan karena kadar airnya berkurang serta memiliki aroma dan

• email korespondensi: ika.pramitha20@gmail.com 
rasa yang tidak terlalu menyengat seperti bawang putih. Dalam black garlic, senyawa $S$-allylcysteine membantu penyerapan allicin sehingga metabolisme perlindungan terhadap infeksi bakteri menjadi lebih mudah. Hasil penelitian Lee (2009) menyebutkan bahwa antioksidan bawang hitam (black garlic) memiliki aktivitas lebih kuat dibandingkan dengan bawang putih dengan nilai TEAC (Trolox Equivalent Antioxidant) secara berturut-turut adalah $(13,3 \pm 0,5)$ dan $(59,2 \pm 0,8)$ $\mathrm{mol} / \mathrm{g}$ basah. Selain itu Black garlic memiliki sifat antioksidan 2 kali lebih tinggi dan sifat antibakteri lebih kuat dibandingkan bawang putih biasa karena mengandung S-allycysteine (Choi et al., 2008). Semakin lama waktu fermentasi black garlic maka kandungan S-allycysteine (SAC) semakin meningkat. Dengan adanya senyawa antioksidan yang lebih tinggi dari bawang putih diharapkan dapat lebih efektif untuk mengatasi suatu penyakit (Bae, 2014). Lama pemanasan pada black garlic paling tidak terdapat perbedaan bermakna munculnya aktivitas antioksidan, sehingga pada pemanasan 21 hari black garlic memiliki aktivitas antioksidan paling tinggi dibandingkan dengan pemanasan hari ke-0 dan ke-7. Karena adanya peningkatan polifenol, flavonoid, dan kandungan asam askorbat selama pemanasan (Xu et al., 2007).

Berdasarkan hal tersebut diatas, belum adanya data yang menjelaskan aktivitas antioksidan yang dimiliki oleh black garlic majemuk ataupun tunggal. Oleh sebab itu, pada penelitian ini dilakukan untuk mengetahui aktivitas antioksidan black garlic tunggal dan majemuk secara in-vitro dengan DPPH. Black garlic yang digunakan pada penelitian ini adalah black garlic yang diproses dengan cara fermentasi selama 3 minggu didalam magic com. Pengujian kapasitas antioksidan black garlic dilakukan menggunakan DPPH sebagai sumber radikal dan asam galat sebagai standar baku yang diujikan dengan spektrofotometer UV-Vis.

\section{METODE PENELITIAN}

Bahan Penelitian. Bahan yang digunakan dalam penelitian ini, antara lain: $1 \mathrm{~kg}$ bawang putih tunggal dan $0,5 \mathrm{~kg}$ bawang putih tunggal yang diperoleh dari pasar Badung, akuades, DPPH (Sigma), pelarut metanol PA (Merck).

Alat Penelitian. Alat yang digunakan pada penelitian ini, antara lain: vial $5 \mathrm{ml} / 10 \mathrm{ml}$, botol coklat, spektrofotometri UV-Vis (UV-1800 Shimadzu double beam), magic com (Yong Ma), kertas saring, kertas tissue, aluminium foil, mortir dan stemper, wadah penimpanan black garlic, pipet tetes, timbangan digital (Acis), labu ukur 5ml, $10 \mathrm{ml}$ dan 25ml (pyrex), beaker glass (pyrex).

Persiapan Sampel. Bawang putih tunggal dan bawang putih majemuk yang telah dikumpulkan selanjutnya di lakukan proses fermentasi selama 21 hari. Hasil yang didapat pada proses fermentasi yaitu berupa black garlic tunggal dan black garlic majemuk yang kemudian digunakan sebagai sampel. Selanjutnya black garlic diblender atau digerus, kemudian hasilnya ditimbang sebanyak 1 gram dimasukkan ke dalam labu ukur $10 \mathrm{ml}$, kemudian dilarutkan dengan metanol sampai tanda batas. Larutan ini yang akan digunakan dalam pengujian aktivitas antioksidan dengan DPPH

Kapasitas Antioksidan dengan DPPH. Larutan sampel dibuat dari sampel black garlic majemuk dan black garlic tunggal dengan konsentrasi 100 $\mathrm{ppm}$. Selanjutnya larutan sampel dipipet sebanyak $1 \mathrm{ml}$ pada dimasukkan ke dalam vial, kemudian ditambahkan larutan baku kerja DPPH 40 ppm sebanyak $4 \mathrm{ml}$, sebagian pembanding larutan baku kerja DPPH 40 ppm dipipet sebanyak $4 \mathrm{ml}$ dimasukkan ke dalam vial ditambahkan metanol sebanyak $1 \mathrm{ml}$ dikocok sampai homogen, kemudian didiamkan selama 30 menit. Selanjutnya diukur dengan spektrofotometri UV-Vis pada masing-masing konsentrasi dan dicatat absorbansinya, kemudian tersebut dilakukan perhitungan presentase dengan rumus:

$\%$ aktivitas antioksidan $=$

$$
\frac{\text { Absorbansi DPPH-Absorbansi sampel }}{\text { Absorbansi DPPH }} \times 100 \%
$$

\section{HASIL DAN PEMBAHASAN}

Bahan yang digunakan pada penelitian ini adalah bawang putih. Bawang putih yang telah dikumpulkan dibedakan jenis yaitu bawang putih tunggal dan bawang putih majemuk. Bawang putih tunggal dan bawang putih majemuk dipilih dan selanjutnya dilakukan proses fermentasi sehingga kadar air dari bawang putih tersebut akan menurun. Dari proses fermentasi tersebut akan menghasilkan bawang hitam (black garlic) majemuk dan black garlic tunggal. Perubahan warna pada proses pemanasan ini disebabkan karena adanya reaksi Maillard. Reaksi maillard adalah suatu reaksi kimia antara asam amino dengan gula pereduksi yang menyebabkan adanya perubahan warna pada makanan menjadi gelap, dan mempunyai bau yang khas, perubahan bau yang khas ini juga terjadi 
karena adanya peningkatan polifenol, flavonoid, dan kandungan asam askorbat selama proses pemanasan (Xu et al., 2007).

\section{Kapasitas Antioksidan dengan DPPH}

Pada penelitian ini ditentukan nilai kapasitas antioksidan black garlic tunggal dan majemuk. Penentuan kapasitas antioksidan pada penelitian ini digunakan standar baku asam galat. Hubungan aktivitas antioksidan asam galat dengan konsentrasi larutan baku asam galat ditunjukkan pada Gambar 1. Pada Gambar 1 menunjukkan persamaan garis aktivitas antioksidan dari larutan baku asam galat yaitu $\mathrm{y}=40.37 \mathrm{x}-2.789$ dengan koefisien korelasi $\left(\mathrm{R}^{2}\right)$ sebesar 0.9999. Hal ini menunjukkan bahwa metode yang digunakan dalam penentuan aktivitas antioksidan asam galat memiliki hasil yang baik dengan nilai koefisien korelasi $\left(\mathrm{R}^{2}\right)=1$ atau -1 (Harmita, 2004).

\section{Hubungan \% Peredaman dan Konsentrasi}

\section{Asam Galat}

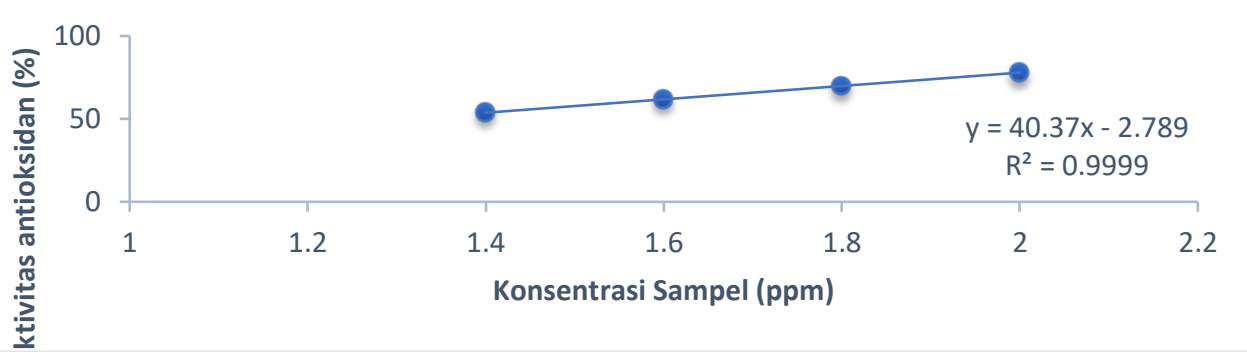

\section{Gambar 1. Kurva Kalibrasi Aktivitas Antioksidan Asam Galat}

Hasil uji antioksidan pada black garlic tunggal dan black garlic majemuk dilakukan dengan peredaman DPPH ditunjukkan pada Tabel 2. Dalam Tabel 2 pada penelitian ini menunjukkan nilai aktivitas antioksidan black garlic tunggal dan majemuk secara berturut-turut sebesar $61.90 \%$ dan $58.96 \%$. Nilai aktivitas antioksidan yang telah didapatkan dimasukkan ke dalam persamaan garis aktivitas antioksidan asam galat yang bertujuan untuk menentukan nilai kapasitas antioksidan sampel yang setara dengan aktivitas antioksidan asam galat. Nilai kapasitas antioksidan sampel dapat dilihat pada Gambar 2. Kapasitas antioksidan yang dimiliki black garlic tunggal dan majemuk secara berturut-turut sebesar $1.529 \mathrm{ppm}$ dan 1.602 ppm ekivalen asam galat. Hasil ini menunjukkan bahwa aktivitas antioksidan yang dimiliki tunggal dan majemuk merupakan antioksidan yang tergolong sangat kuat. Berdasarkan data yang ditampilkan pada Gambar 2, nilai kapasitas antioksidan black garlic tunggal lebih tinggi dibandingkan dengan nilai kapasitas antioksidan yang dimiliki oleh black garlic majemuk.

Tabel 1. Aktivitas Antioksidan Black Garlic Tunggal dan Majemuk

\begin{tabular}{lcc}
\multicolumn{1}{c}{ Sampel } & Absorbansi & Aktivitas Antioksidan (\%) \\
Kontrol & 0.833 & 0 \\
Black Garlic Tunggal & 0.315 & 58.96 \\
Black Garlic Majemuk & 0.339 & 61.90 \\
\hline
\end{tabular}

Hal ini menunjukkan bahwa pada black garlic majemuk memiliki kapasitas antioksidan yang lebih rendah dibandingkan pada black garlic tunggal. Berdasarkan Utami (2013) menyebutkan bahwa aktivitas antioksidan pada black garlic tunggal memiliki aktivitas antioksidan yang lebih besar. Hal ini dikarenakan senyawa aktif yang berupa allicin dan saponin dalam satu suing black garlic tunggal 2 kali lebih besar dibandingkan black garlic majemuk.
Fenolik dalam tanaman memiliki fungsi sebagai pereduksi yang menyumbangkan atom hidrogen dan sebagai antioksidan yang mampu meredam terbentuknya radikal bebas. Flavonoid merupakan turunan dari senyawa fenol. Flavonoid yang terkandung dalam ekstrak etanol bunga pacar air merah dan gemitir kemungkinan adalah flavonoid yang mengandung banyak gugus gula dan banyak mengandung gugus hidroksil, seperti 
antosianin dan kaempferol (Pratheesh et al., 2009; Hua et al., 2001).

Kapasitas antioksidan yang dimiliki oleh black garlic majemuk dan black garlic tunggal merupakan antioksidan yang tergolong sangat kuat karena memiliki nilai konsentrasi kurang dari 50 ppm. Hal ini dikarenakan bahwa black garlic memiliki senyawa S-allycysteine. Aktivitas antioksidan menunjukkan adanya penurunan nilai absorbansi dari DPPH yang diberikan larutan uji dengan konsentrasi meningkat. Penurunan nilai absorbansi menunjukkan bahwa telah terjadi peredaman terhadap radikal bebas dari DPPH oleh senyawa antioksidan dalam larutan uji yaitu black garlic majemuk dan black garlic tunggal. Penurunan nilai absorban disebabkan oleh penurunan intensitas warna DPPH dari ungu menjadi kuning. Reaksi yang terjadi oleh DPPH dengan senyawa pada larutan uji adalah pembentukkan DPPH radikal bebas, melalui kemampuan antioksidan menyumbang hidrogen.

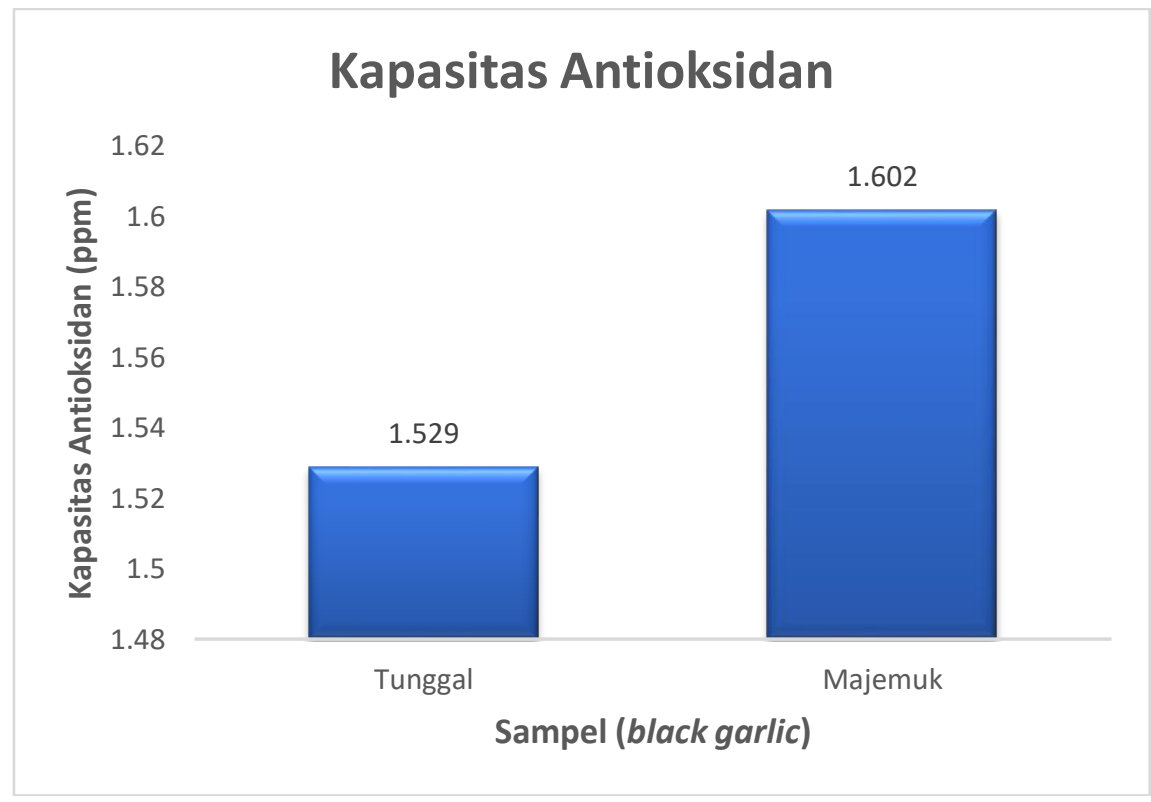

Gambar 2. Kapasitas antioksidan sampel black garlic

\section{SIMPULAN}

Berdasarkan hasil yang telah didapatkan pada penelitian ini dapat disimpulkan bahwa nilai kapasitas antioksidan black garlic tunggal dan majemuk secara berturut-turut sebesar $1,529 \mathrm{ppm}$ dan 1,602 ppm ekivalen asam galat.

\section{UCAPAN TERIMA KASIH}

Terima kasih diucapkan kepada Staf Laboratorium Bersama FMIPA Universitas Udayana yang telah membantu dalam kelancaran penelitian ini.

\section{DAFTAR PUSTAKA}

Ambarsari, I.Q. (2013). Penerapan Standar Penggunaan Pemanis Buatan pada Produk Pangan, Semarang: Balai Pengkajian Teknologi Pertanian Jawa Tengah
Bae, S.H., Cho, S.Y., Wox, Y.D., Lee, S.H., dan Pord, H.J. (2010). Infuence of Steeping Solution and Stroge Temperature on the Color Change of Garlic Journal Food Science 75 (1) : C108-C112

Choi, J.G., Kang, O.K., Lee, Y.S., Oh, Y.C., Chae, H.S., Jang, H.J., Shin, D.W., and Kwon, D.Y. (2008). In Vitro Activity of Metyl Gallate Isolated from Galla Rhois Alone and in Combination with Ciprofloxacin Agains Clinical Isolates of Salmonella, J. Microbiol. Biotecnol. 18 (11) : 1848-1852

Harmita. (2004). Petunjuk Pelaksanaan Validasi Metode dan Cara Perhitungannya.Majalah Ilmu Kefarmasian, Vol. I, No.3. Hal. 117135.

Lee, Y. M. (2009). Antioxidant Effect Of Garlic And Aged Black Garlic In Animal Model Of Types 2 Diabetes Melitus. Nutrition Research And Practice, Vol 3 (2). Hal: 156-162 
Pratheesh, V.B., Benny, N \& Sujatha, C.H. (2009). Isolation, Stabilization and Characterization of xanthophyll from Marigold FlowerTagetes erecta-L. Modern Applied Science. 3(2): 19-28

Wang, D., Feng, Y., Liu, J., Yan, J., Wang, M., Saki, J. (2010). Black Garli (Allium sativum L.) extracts enhace the immune system. Medicinal and Aromatic Plant Science and Biotecnhology. (4) :37-40
Wang, W., \& Sun, Y. (2017). In vitro and in vivo antioxidant activities of polyphenol extracted from black garlic. Food Science and Technology, 37(4), 681-685.

Xu, G.; Ye, X.; Chen, J.; Liu, D. (2007). Effect of heat treatment on the phenolic compounds and antioxidant capacity of citrus peel extract. J. Agric. Food. Chem. 5(5) : 330335 